This item was submitted to Loughborough's Research Repository by the author.

Items in Figshare are protected by copyright, with all rights reserved, unless otherwise indicated.

\title{
Police and media relations in an era of Freedom of Information
}

PLEASE CITE THE PUBLISHED VERSION

http://dx.doi.org/10.1080/10439460903281513

\section{PUBLISHER}

Routledge (@ Taylor \& Francis)

VERSION

AM (Accepted Manuscript)

LICENCE

CC BY-NC-ND 4.0

\section{REPOSITORY RECORD}

Cooke, Louise, and R. Paul Sturges. 2019. "Police and Media Relations in an Era of Freedom of Information". figshare. https://hdl.handle.net/2134/6577. 
This item was submitted to Loughborough's Institutional Repository (https://dspace.lboro.ac.uk/) by the author and is made available under the following Creative Commons Licence conditions.

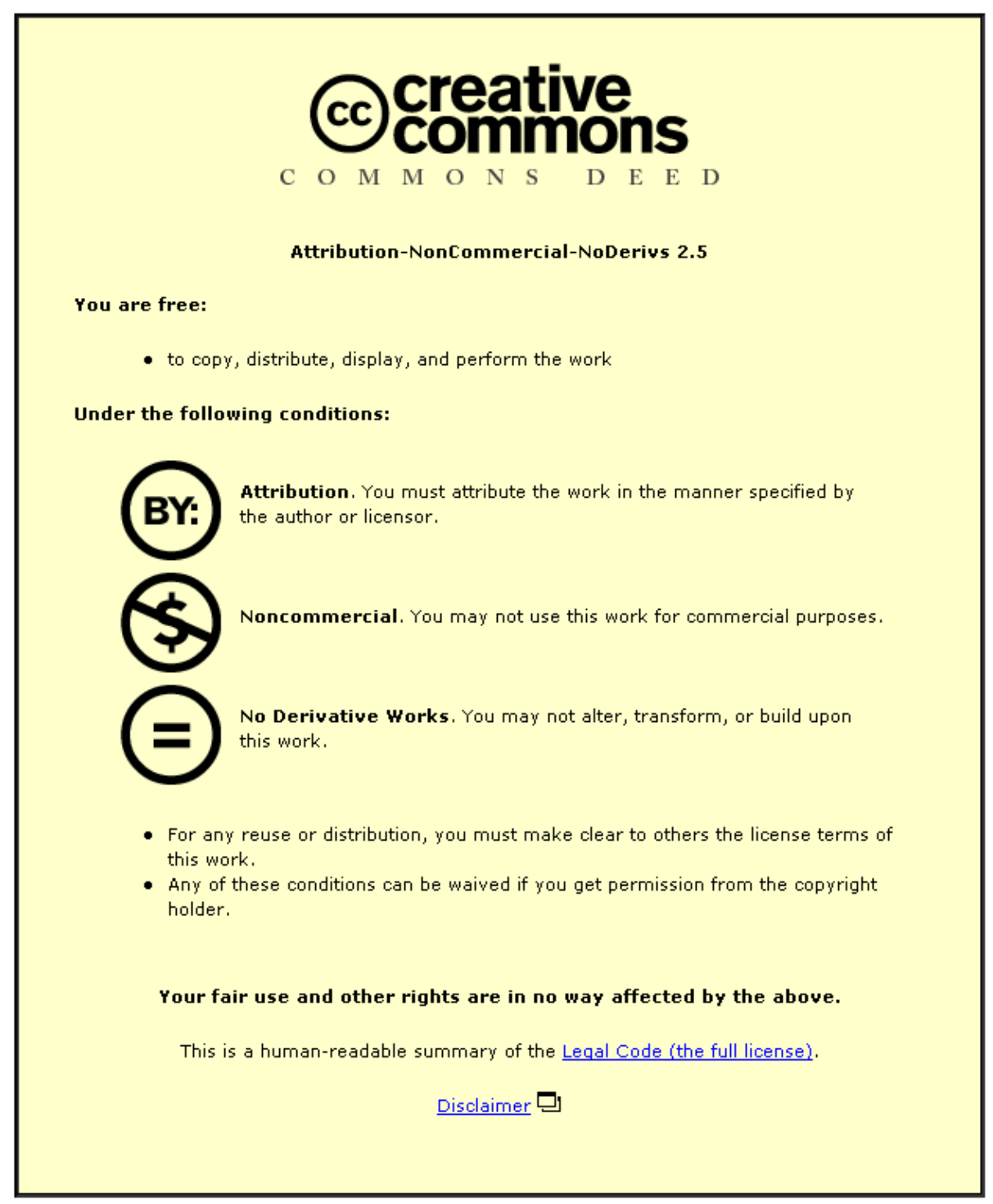

For the full text of this licence, please go to: http://creativecommons.org/licenses/by-nc-nd/2.5/ 


\title{
Policing and Society
}

Vol. X, no. X, Month 200X, 000-000

\section{RESEARCH ARTICLE}

Police and Media Relations in an Era of Freedom of Information

\begin{abstract}
Changes to how police forces in England and Wales are working to manage their public image in an environment of heightened accountability and transparency are explored. The locus of control of information shaping the portrayal of the police in the news media is discussed, as is the impact of the Freedom of Information Act 2000. The findings from case studies of two police forces in the East Midlands are reported. The case studies indicate that, whilst police and media co-operation is not a new phenomenon, UK police forces are becoming increasingly proactive, strategic and professionalized in their use of the news media. For their part, the media are dependent on the news 'fed' to them on a regular basis by police press relations units. Nevertheless, thanks in particular to their use of the FOIA 2000, the media continue to play a role as independent watchdog and reporter of police activity.
\end{abstract}

Keywords: police; media; freedom of information; transparency; accountability 


\section{Police and Media Relations in an Era of Freedom of Information}

\section{Introduction}

In this paper, we explore recent changes to how police forces in England and Wales are working to manage their reputation and public image in an era where concepts such as transparency, neighbourhood engagement and community policing are high on the public policy agenda. In particular, the locus of control of information shaping the portrayal of the police in the news media is discussed, as is the impact of the Freedom of Information Act 2000 (Great Britain 2000) on police control of information disclosure. In addition to review of some of the extensive body of work investigating police and media interaction, the paper reports the findings from case studies of two police forces in the English Midlands: Derbyshire Constabulary and Leicestershire Constabulary. The focus of the studies relates to police and media interaction with regard to the reporting of crime news and 'police stories' in the press, rather than fictional or 'reality TV' portrayals of police work in television or film broadcasting. Empirical work took place over a two-month period in September and October 2007, and involved analysis of documentary and electronic materials, participant observation, and semi-structured individual and group interviews. The demography of the two counties suggests that they are reasonably representative of the UK policing context: nevertheless, we recognise the need for caution in drawing generalisations from these two cases. As a starting point for further investigation, however, we believe that this preliminary exploration offers some useful and interesting findings.

\section{Police and the news media: a complicated relationship}

Willingly or not, it has long been recognised that the police and the media can be seen to be locked into a relationship that is, to some degree at least, premised on what Reiner has described as a 'complex loop of interdependence' (Chibnall 1977, Ericson et al. 1989, Boyle 1999, Reiner 2000, Chermak and Weiss 2005, Reiner 2008). Sir Robert Mark, Commissioner of the Metropolitan Police from 1972 to 1977, went so far as to describe the relationship between the police and the press as 'an enduring, if not ecstatically happy, marriage' (Chibnall 1977, Chibnall 1979, Mawby 2002b, Reiner 2008). The media depend on the police for the constant release of "crime and crash" information as the lifeblood of their news stories (Chibnall 1977, Ericson et al. 1989, Ericson et al. 1991, Crandon 1992, Crandon and Dunne 1997, Reiner 2008); and the police depend on media coverage for help in crime prevention and detection and in the promotion of a positive image of policing work (Chibnall 1977, Chibnall 1979, Ericson et al. 1989, Chermak and Weiss 2005, Reiner 2008). Reiner (2000, p.139) also highlights the exploitation of the media by the police to 'construct crime waves' in order to gain prestige or to secure resources. In an environment of community policing, the media act as a primary means for the police to communicate with their neighbourhood constituencies (Chermak and Weiss 2005). Boyle (1999) suggests that the relationship between the police and media has undergone a period of change, as a result of a 'crisis of legitimacy' in which police services have had to transform themselves into demonstrably accountable organisations providing a value-for-money service to the public. Part of this change has involved embracing, rather than merely tolerating, the role of the media to manage their public image in a “culture of promotionalism” (Ericson et al. 1989, Schlesinger and Tumber 1994, Boyle 1999). In this venture they face the same difficulties as other organisations in determining how to protect themselves against unwanted intrusion from the media, whilst at the same time ensuring that they achieve favourable external publicity (Ericson et al. 1989, Mawby 2002b). 
This cultural shift has led to an increasing professionalization of police handling of the media, with UK police forces now embracing the role of corporate communications units (Leishman and Mason 2003, Mawby 2002b). The Metropolitan Police Service was the first to establish an official Press and Public Relations Office in 1919 (Chibnall 1977, Chibnall 1979, Crandon 1992, Mawby 2002b); now, despite - or perhaps because of - an inherent tendency on the part of the police to mistrust the media (Chibnall 1977, Chibnall 1979, Mawby 1999, Reiner 2000), all 43 police forces in England and Wales have departments with specific responsibility for media relations, staffed primarily by civilian personnel who often include former journalists or marketing specialists (Ericson et al. 1989, Crandon 1992, Boyle 1999, Mawby 1999, Mawby 2002b, Leishman and Mason 2003). Adopting a proactive stance towards media communication, such units provide pre-packaged news materials for media outlets, as well as arranging press conferences and offering media access to police events and activities, such as dawn raids. All forces also maintain a web presence, with many now developing interactive e-policing services (for example, 'report a crime online'). To quote from Boyle (1999, p.231),

Thinking strategically about image and media management has become central in the development of operations aspects of policing, and can no longer be simply dismissed as an optional extra for the police.

Research carried out by Crandon and Dunne with the Avon and Somerset Constabulary (Crandon and Dunne 1997) demonstrated that, of all police/ media interactions that took place within the Constabulary in 1993, 92.56\% were police-initiated. Further, $92.47 \%$ of these police-initiated briefings were taken up and used by the media, suggesting a high level of police control over the nature of crime reports seen by the general public. And it is not just over which events get reported that the police are able to exercise control: as Chibnall (1977) and Ericson et al (1991) point out, news reporters rarely witness directly the events that they report: they are reliant on the selective accounts to which they have access of these events, and their consequent social construction. The issue of control of media reporting of crime and policing news is a critical one. How the media frame such news has considerable power to influence political debate and public perception of events (Chibnall 1977, Ericson et al. 1991, Crandon 1992, Reiner 2000): for example, using headlines such as 'Shot Brazilian was here with a fake visa' (Rayner 2005) and 'Stockwell victim was high on cocaine' (Walters 2006) in connection with the killing of Jean Charles de Menezes could be argued as a means to deflect attention away from police action.

Notwithstanding this increased level of sophistication towards media management on the part of modern policing organisations, Mawby (2002a, 2002b) argues that in a context of increasing organisational and technological complexity, and a media environment that is less easy to control, conventional views that the police dominate and manipulate the police-media relationship (for example, see Hall et al. 1986), need reexamination. Reiner (2000) notes that journalists have traditionally been seen by the police as 'challengers' who have the power to penetrate police secrecy, leading to efforts on the part of the police to attempt to 'colour what they see' (Reiner 2000., p.94). Although media portrayal may help to legitimate police work, it could be argued that with regard to high profile news events such as the Hillsborough football stadium disaster, the Stephen Lawrence murder, the media do still play an important 'watchdog role'(Mawby 1999). Exposure of alleged aggressive policing tactics during the G20 protests in London in 2009 could be seen as an example of the media playing just such a role. Ericson et al. (1989) also highlight the fact that control of published content rests ultimately with the media who determine the final copy that goes to press, and that the police have no power to restrict publication. But at the same time, it is noted that the media are dependent on access to sources that they must strive not to offend, and that censorship, including self-censorship, will thus 
inevitably take place. In addition, factors such as the laws of libel; the command structure of policing organisations; the centralisation of the PR function within such organisations; informal agreements between the police and the media not to publish certain stories or accounts; and the potential negative impact of publication on ongoing investigations, trials, suspects, victims, or even on police workloads can all serve to constrain the reporting of police and crime news (Chibnall 1977, Ericson et al. 1989).

If the news media have a role to play in promoting a certain public image of police services, their impact on public perceptions with regard to levels of crime and fear of crime is arguably even greater. Although it is difficult, if not impossible, to measure the direct impact of the media on levels of fear of crime, it has been shown that stories relating to crime receive a disproportionate amount of media coverage compared with other social issues (Chibnall 1977, Reiner 2000, Leishman and Mason 2003, Reiner 2008). Moreover, the focus of such stories does not reflect actual crime patterns, but tends towards those relating to more serious violent and sexual crimes, and to those that portray the victims of crime as fitting the stereotype of the mature, affluent and respectable citizen (Chibnall 1977, Reiner 2000, Cohen 2002, Leishman and Mason 2003, Reiner 2008). In so doing, such coverage serves to establish and reinforce community norms and values, and thereby 'to appropriate the moral conscience' of those who read it (Chibnall 1977, p.xi). This disproportionate coverage is not just a recent phenomenon: Cohen describes how in 1966, the Clacton Evening Argus used a subheading of 'Violence' to report that 'in Brighton, there was no violence in spite of the crowds of teenagers on the beach' (Cohen 2002, p.27). The media can be seen to be influential in helping to define and frame the public policy agenda with regard to crime: for example, by focussing attention on issues such as 'bogus' asylum seekers, binge drinking and gang wars (Cohen 2002). In a similar fashion, in July 2008 The Guardian used a heading of 'Crime rates expected to soar as economic difficulties deepen' to report that there had been a fall of $10 \%$ in crime levels over the preceding 12 months, and an overall $48 \%$ decline in crime since the peak year of 1995 (Travis 2008, p.6). On the other hand, it has been suggested that by focusing on the reporting of crimes that have led to successful arrests and prosecutions, media portrayals of policing tend to distort the picture with regard to crime clear-up rates in favour of the police (Leishman and Mason 2003, Reiner 2008). Boyle takes this argument even further, by maintaining that the news media can exert a real effect on actual levels of crime, for example by creating an impression of increased police activity (Boyle 1999).

\section{Changing public policy contexts}

Policing in the UK has undergone a process of rapid and significant change in recent decades, and much of this change relates to the management, sharing and use of information. Despite the fictional image beloved by the media and the public alike that portrays days and nights on patrol, fights and car chases, and cases solved by the brilliant insights of individuals, it has been argued that policing has always been essentially an information handling profession (Ericson and Haggerty, 1997) although this perspective has been subject to much debate. Nevertheless, the effective management and use of information has an important role to play in crime prevention, reduction and investigation strategies and the amount of information that police officers encounter in the course of their work is considerable (Ericson and Haggerty 1997, Luen and Al-Hawamdeh 2001). This is despite the contention of Brodeur and Dupont (2006) that informational work ('shuffling paper') is perceived by individual officers as being of little value and carrying no prestige within policing organisations. Indeed, the importance of information processes in the detection of crime and the maintenance of law and order have become ever more apparent as pressures for increased transparency and disclosure, such as implementation of the Freedom of Information Act 2000, have impacted on the policing profession. 
Whereas in previous era, much of the operational activity of policing, and the records arising from it, were not open to public scrutiny, police forces in the UK now operate in a climate where public bodies and members of the public demand a high level of transparency, performance measurement and information disclosure. This could be seen in part, but not solely, as attributable to the impact of freedom of information legislation. In addition, high profile incidences of failure to pass on information between police forces and other agencies have increased the need to scrutinise the communication patterns of policing organisations. Thus, for example, the terms of reference of the Bichard enquiry, investigating the circumstances relating to child murders in the village of Soham in Cambridgeshire, included an assessment of police information sharing with other agencies. This concluded that the lack of clear, understandable, national standards and guidance on the subject of information sharing and of record creation, retention, review and deletion, had contributed to the tragedy (Bichard 2004). This recognition led to the drafting of a Code of Practice on the Management of Police Information (MOPI) (National Centre for Policing Excellence 2005), together with guidelines for implementation of the Code (National Centre for Policing Excellence 2006), which challenged the UK police service to move forward from a culture of information storage to one of information management and sharing. In addition to ensuring consistency between Forces in the way that information is managed, the Code of Practice aimed 'to ensure effective use of available information within and between individual forces and other agencies, and to provide fair treatment to members of the public' (National Centre for Policing Excellence 2005).

The emergence of police forces that are arguably both more effective as handlers of information and more open to the scrutiny of outsiders than before is, of course, still a work in progress. Gottschalk and SolliSaether suggest that occupational culture is 'shaped by the socially relevant worlds of the occupation' (Gottschalk and Solli-Saether 2007): in the context of a highly deferential and hierarchical organisation such as a police service, where individuals regularly encounter public confrontation and personal danger, a cultural bias that favours secrecy, self-protection, violence and the closing of ranks when under threat would not be unusual (Chibnall 1979, Christensen and Crank 2001). Chibnall (1977 and 1979) and Mawby (2002b) trace the beginning of a move towards greater openness on the part of the police, to the appointment of Sir Harold Scott to the post of Commissioner of the Metropolitan Police in 1945. Nevertheless, writing in the 1970s, Chibnall noted that the informal name given to the Scotland Yard Press by crime correspondents was the 'Suppress Bureau', and that its representatives, the Divisional Liaison Officers, were jokingly referred to as the 'Don't Let Ons' (Chibnall 1977, p.148). Mawby (2002a and 2002b) notes that Sir Robert Mark, has been credited with a move away from a culture of 'tell them only what you must' to one of 'withhold what you must', thus encouraging a greater ethos of openness between the Metropolitan Police and the news media. This policy of 'openness' was based on a premise that the media could be useful as an ally in the fight against crime and as a means of boosting public belief in the police as well as improving morale within the force (Ericson et al. 1989). However, speaking from the context of the Netherlands, Muller (2002) contends that, despite extensive academic debate on the subject of police accountability, there is still a need for greater transparency with regard to police decision-making. This may indeed be the case, but it is nevertheless apparent that police forces in England and Wales increasingly have to confront the need to regard information about themselves and their activities as a matter for sharing with a multiplicity of stakeholders. This change appears to be driven by a range of factors that together have resulted in a cultural shift towards an increased openness.

Legislation not specifically directed at police forces has contributed to this change: first of all the relevant clauses of the Human Rights Act, 1998 (Great Britain 1998a), the contribution to this ethos of the Public Interest Disclosure Act, 1998 (Great Britain 1998b), and most significantly the Freedom of Information Act 
2000 (Great Britain 2000). Relevant policy initiatives include the Modernising Government agenda of the Blair government, which focussed on a commitment to public sector reform, including making public sector bodies more accountable to their users (Parliament 1999). This in turn led to a programme of police reform outlined in a White Paper Building Communities, Beating Crime: A Better Police Service for the $21^{\text {st }}$ Century, which aimed to build 'a more responsive police service with neighbourhood policing at its heart' and to improve the way the police are held to account (Home Office 2004). Specifically, with regard to information provision, the White Paper commented that

Local people need to be clear who is responsible for what in terms of community safety. They need to understand how they as individuals, families and members of the community, can play a role in keeping their communities safe and reducing crime; how they can have a say in setting local priorities, and how well their local police are performing. This information needs to be available to every household and people should know what they can do...if local problems are not being tackled effectively. (Ibid, p.10)

The increased capacity to communicate demanded by such measures has, in turn contributed to an increased ability to address priorities through the means of communication. Intense public interest in policing, and vociferous criticism of perceived failures and inadequacies, reflected in and sometimes fuelled by, the media have demanded a response. In responding to this pressure, it is arguable that the police discover that an increased openness can lead to the ability still to retain some control over the media agenda, whilst enlisting the public more closely into their decision-making and day to day activity.

\section{Freedom of information}

The UK Freedom of Information Act 2000 (FOIA) came into force on the $1^{\text {st }}$ January 2005, and requires all public authorities to provide a general right of access to information held by them, subject to certain exemptions (for example, although police organisations are not exempt from the provisions of the Act, information about ongoing criminal investigations is exempt). Individuals making a request must be informed whether the requested information is held and, unless it falls within the permitted exemptions, should be given access. It has been suggested that this has resulted in a shift towards viewing information as a form of corporate evidence of activities rather than as a form of private documentation (Screene 2005). Screene also comments that, whilst most public bodies have struggled to meet the requirements of the FOIA, police services in England and Wales have demonstrated strong leadership in its implementation as a result of management recognition of the potential benefits to be gained from increased openness (ibid.). Of course, police forces could not pursue effective investigations and bring cases to court successfully without excellent record-keeping. Under the freedom of information regime, it is required that a publication scheme is made available, revealing just what every 'public authority' already 'publishes' in some form or other. Naturally the nation's police forces generate bodies of material that have a great deal in common. This made it possible for the Association of Chief Police Officers (ACPO) to coordinate the creation of publication schemes across the country, resulting in the adoption of a common approved publication scheme in all 43 forces (Readhead 2004).

However, research in other jurisdictions indicates that police forces elsewhere initially underestimated the impact that the FOIA would exert on their workload (Chinchen and Morris 2005). For example, on implementation of freedom of information legislation in the US, the FBI allocated 15 employees to manage requests: by 2005 this number had risen to around 230 (ibid.). The Metropolitan Police Service are reported to 
have received more than 2,000 FOIA requests during the first six months of implementation of the Act, leading them to an apparent recognition that it is more time effective to integrate the proactive publication of information into normal business practices (Shepherd and Ennion 2007). Recent figures suggest that altogether police services in England and Wales currently field more than 20,000 requests a year for information under the FOIA, and that the number of requests being made increased by around $50 \%$ between 2005 and 2007 (Readhead 2007). Of the requests received, approximately 45\% emanate from the mass media (ibid.). It has also been noted that FOIA requests are increasing in complexity, particularly where 'professional' users of the legislation (mainly journalists and lawyers) are making the requests (ibid.). Meanwhile, Readhead has highlighted the specific difficulties faced by police services in responding to FOIA requests, especially with regard to vexatious enquiries and those intended to undermine law enforcement (Readhead 2004). For example, he cites the practice of making a series of seemingly different 'innocuous' requests, that put together allow the enquirer to extract compromising information such as the identity of confidential intelligence sources.

\section{The impact of neighbourhood policing}

The implementation of a strategy of neighbourhood policing in the UK, as endorsed by the 2004 White Paper Building Communities, Beating Crime (Home Office 2004) and reinforced in the 2008 policing Green Paper (Home Office 2008) has required considerable organisational and cultural change on the part of policing organisations and individual officers (Van den Broek 2002 ). In this environment, presence on the streets is not enough: police officers need to engage in direct contact and interaction with members of their local communities. Indeed, in itself a strategy of community policing can be considered as an exercise in image management on the part of the police, who are projected as a body that is responsive and attuned to community concerns (Chermak and Weiss 2005). Members of the public are seen as stakeholders who are entitled to their say in determining policing priorities and approaches, as well as volunteering information with regard to local crime and disorder. However, this new espousal of consultation may not always operate as democratically as intended: Van den Broek's research found that residents 'experienced the openness of the police towards the public as selective' (Van den Broek 2002, p.174), paying more attention to those with political influence, or who shout the loudest, or who know how to use the media to push their own viewpoint. It is suggested that this carries the risk of police services aligning their resources and priorities with proactive initiatives from well-organised and vocal community groups in defence of their own specific interests, such that community policing is oriented towards those groups who arguably have least need of it (Stenson 1993, cited Van den Broeck 2002, p.186).

\section{Case study methods}

A qualitative exploratory approach was adopted for the empirical element of this study. Field work consisted of two small-scale case studies, using a combination of analysis of documentary and electronic materials, observation, and semi-structured individual and group interviews. Leicestershire and Derbyshire Constabularies were chosen as case study sites, primarily on the basis of existing contacts and hence ease of access to personnel and documents. However, demographic and organisational statistics also suggest that they can be considered as reasonably representative English forces, both in terms of community profile and force characteristics, encompassing as they do both isolated rural areas and large ethnically diverse inner-cities. Thus, for example, the 1,000 plus square miles policed by Derbyshire Constabulary include the rural areas of the High Peak and Derbyshire Dales, former mining towns and villages, and the City of Derby. Similarly, 
Leicestershire Constabulary's territory encompasses rural market towns such as Oakham and Melton Mowbray and the surrounding small farming villages, alongside Leicester, one of the most culturally diverse cities in the UK.

Field work for the studies involved a combination of individual and group semi-structured interviews, participant observation and documentary analysis. Personnel who participated in the interviews included those with overall responsibility for corporate communications, for liaison with news media, for information management and for Data Protection and Freedom of Information. This included a one-to-one interview with the Head of Corporate Communications for Derbyshire Constabulary, and a group interview with the Head of Public Relations and two members of the Data Protection and Information Management team, responsible for responding to freedom of information requests, at Leicestershire Constabulary. In both Forces, responsibility for corporate communications and for information management is split between different operational departments. Participant observation took place at three public consultation forums concerning budgetary priorities and targeted local crime responses. A range of informational and promotional documents and electronic resources, emanating from both forces, were also analysed.

\section{Findings}

\section{Communications units}

Both forces have well-staffed professional corporate communications units, with 11 (Leicestershire) or 12 (Derbyshire) staff, some of whom are trained journalists, and a dedicated budget for communication activities. It was suggested that in the past formal communication with the public tended to be driven by the legal requirements to report on quantitative and financial aspects of the work of each police force: now, as government priorities have shifted the emphasis towards disclosure and consultation, there is a requirement to hold regular public consultative meetings. Such transparency was reported to be supported from the very highest level of each of the forces, with senior appointments now tending to be made from officers who buy into an ethos of openness: this has quite quickly influenced practice in the forces. Another driver for an increasingly professional and proactive approach to communication was acknowledged to be the need to balance and manage media comment, in an effort to ensure maintenance of reputation. External communication was typically directed at three groups: the general public, either via the media or, increasingly, by direct communication; partner agencies; and interested parties (for example, the victims of crime). They have also targeted their efforts at improving internal communication: for example, the Derbyshire Constabulary wanted to improve communication with Special Constables, and so the communications unit arranged targeted seminars and now produce a quarterly newsletter specifically for them.

\section{Community engagement}

The whole pattern of police communication in both case study police forces is built on intense grassroots activity. Members of the communications teams stressed the primacy of face to face communication between officers and the public both in disseminating messages and in obtaining insights and intelligence. Both forces were able to give examples of how increased communication with the public has led to enhancements in investigation performance and crime solving, such as in the case of missing persons. This pattern of 
communication involves the use of meetings and publications, supported by the use of telecommunications media. This was characterised as including police surgeries, visits to schools and youth groups, partner/agency work with bodies such as parish councils and Neighbourhood Watch groups, road shows as part of recruitment drives and many other informal and semi-formal means of contact. 'Street briefings' by officers on patrol are also a means by which exchanges take place with the public on matters such as priorities for surveillance and intervention. The Leicestershire force takes a stall in Loughborough market on a regular basis, so that the public can be informed about matters including crime prevention and personal safety. Identification and action on 'signal crimes' such as graffiti and littering, which contribute to public fear of crime, can be intensified through this type of contact. Such public activities are reinforced by regular witness appeals and 'a flow of positive stories to the press: the Communications Office keeps the Leicester Mercury in business’ (Leicestershire Constabulary).

There can also be a political aspect to community engagement and consultation. For instance in Derbyshire the response to a proposed merger with neighbouring police forces took the form of intense communication with the public through seminars, surveys, online and postal, and relevant website content. The resulting abandonment of the merger plans were felt to be equally owned by the police force and the public. Also in Derbyshire, the response on the part of the police to a slightly higher than average fear of crime and perception that crime rates were high, has been to communicate better with the public to reassure them that, in fact, Derbyshire is measurably safer than otherwise comparable counties. The situation seems to be that police forces having perhaps somewhat unwittingly moved into an arena of greater openness for a complex of extrinsic reasons, now find themselves reaping significant benefit from this more transparent environment and offering greater disclosure as a matter of operational choice.

Central to this approach is a policy of neighbourhood policing. Derbyshire, for instance, is divided into 103 neighbourhoods, each with its Safer Neighbourhood Team. These are considered to be the chief channel of communication to the public, and source of intelligence from the public. The Teams are made up of locally based police officers, Police Community Support Officers (PCSOs), special constables, park wardens and others. These teams, particularly their PCSO members, are seen as providing one of the few constant local presences (given the closure of village and neighbourhood shops and post offices and the loss of many unprofitable local public houses). In Derbyshire the communications unit has four Community Officers supporting the work of the teams with materials such as posters, and publicity in the media.

A pattern of events, campaigns and other activities have then been constructed on this basis of widely distributed communication. For instance, Derbyshire launched its Operation Relentless in May and June 2007 as a high profile campaign to reduce the incidence of crime, improve detection rates and raise the visibility of policing activity. This involved a number of specific policing operations, for which an $8 \%$ reduction in crime, a $6 \%$ increase in detection and a $14 \%$ increase in arrests were claimed over a 61 day period. Associated with the campaign were 'Relentlessly Attacking Crime' seminars for the public, with demonstrations of police technology, dogs and the use of the police helicopter. In October 2007 the campaign was renewed with a focus on violent crime and anti-social behaviour; again with associated seminars in the north and south of the county. This combination of a targeted policing campaign linked to a publicity campaign seems to typify a major approach by police forces to integrating the role of communication in their activities. Other examples of localised communication are events such as Derbyshire's first Safer Neighbourhood Week, in which the public were invited to meet senior officers, visit police facilities and learn about the partnerships with other agencies. The police contributed to Liberation Day events, in which older citizens were encouraged to liberate themselves from the fear of crime. 
More formal events share the same ethos of exchanging information and opinion rather than merely publicising the police position. For instance the budgetary consultation meetings held in Derbyshire in late 2006 involved the Chief Constable and financial officers making presentations about the budgetary options available in the spending of the next year's financial allocation. The cost of particular forms of operation was revealed and the ability to prioritise certain forms of policing in this financial context was set out. The public audience was then able to ask questions and make their points on expenditure priorities. In the same spirit, 25 'Have Your Say' events were held in 2006-7 at a range of venues including supermarkets, market places, university premises, hospitals, parks, libraries. Questionnaire responses on policing priorities and other matters were collected, and an adapted version of the budget consultation materials was used to extend the financial consultation process. At the same time,

The events were designed to inform the public of Derbyshire about its police force. A wide range of literature relating to the Force and its performance was made available; annual reports, budget and Safer Neighbourhood team information was provided, as were small cards which were used to emphasise the force non-emergency number. (Derbyshire Constabulary 2007, p.9)

\section{Publications}

In the quite recent past the main print on paper item distributed by the Leicestershire force was the Annual Report. It was made publicly available in libraries, but today it is also available through the force's website. Since April 2006 this has been reinforced by a statutory requirement on police authorities to produce annual 'Local Policing Summaries' to be distributed to every household in their area. This requirement was introduced with the statement that:

The government is committed to strengthening community engagement in policing and believes that the provision of information on how local policing is being delivered is central to this...Providing better information on local policing is also important as it supports the need to make policing truly accountable and transparent to the public. (Home Office 2006, p.2)

Arguably, our case study forces (along with many others) have gone significantly beyond this minimum requirement. In Leicestershire for example, there are now a range of glossy A4 publications led by Your Police. This is a newsletter, which carries a variety of short items illustrated with colour photographs dealing with changes and developments, policing successes, campaigns, and stories about police and community personalities. The same format and similar content is given a more local slant in Local Policing in Rutland (or any of the other areas served by the Leicestershire police). Finally there are neighbourhood newsletters with content aimed at specific districts, small towns and groups of villages, even individual streets, and presented as messages from the named neighbourhood beat team.

The pattern and content in Derbyshire is similar. Policing Derbyshire is described as the Annual Report. The 2005-6 edition is in newspaper format on glossy paper with colour illustrations. It adopts the friendly approachable style now becoming the norm for this type of material, breaking the statistics and statements down into separate news stories and also providing news from the various areas of the county. A noticeable item, headed 'Open and Transparent' draws attention to a step by step guide to the complaints procedures now available via the website. The same item gives basic figures for the complaints received during the year. There is also a smaller item to the effect that 390 freedom of information requests had been received. Derbyshire's Safer Neighbourhood News newsletters link to the activities arising from the priorities identified by the Safer 
Neighbourhood teams and also provide contact details and information on how to make complaints. The police force also feeds material into Safer Derbyshire, issued by the County Council. This glossy A4 publication, distributed free to every household, deals with a range of community and individual safety issues that include and go beyond policing. In all of these publications in both forces, the text and pictures are very professionally done and support each other in projecting a positive and 'cosy' message of openness, and of local officers and police partners out there, working in the community and available to give and receive help and information.

\section{Electronic media}

In the last three or four years the websites of police forces have come to be the focal aspect of their communication. They have their own '.police' domain; desk research suggests that their quality is mostly of a high professional standard; and they carry considerable volumes of important information. They provide routine material such as the text of reports and newsletters, minutes of meetings; but also messages from beat officers and direct appeals to the public (which sometimes bypass the media and have achieved a certain success in dealing with cases). They are extensively used for recruitment activity and they are central to freedom of information response. The websites are used to project a consistently positive message about the force and its relationship with the public. For instance, a particularly appealing aspect of the Derbyshire website is its 'Young Space' area (Derbyshire Constabulary n.d.). This uses plain but lively language and high quality graphics (a plump crocodile police officer features) to tell children about police work, advise them on personal safety and amuse them with 'Fun Stuff'. The section that allows you to create a comic photo fit online is to be recommended for adults too. However, Devon and Cornwall Constabulary went a step further. A news release tells of the sticker albums issued in Brixham that enabled children to approach officers and PCSOs to ask them for a sticker with their picture on it (Devon and Cornwall Constabulary 2007).

All forty-three forces in England and Wales provide online information about freedom of information and access to their publication scheme on their website, although the prominence and ease of access to this information does vary between the forces. The Derbyshire site, for instance has a freedom of information section accessible from the home page via a direct and clearly visible link entitled 'Freedom of information'. The Leicestershire Constabulary site also leads into its freedom of information section through a link on the home page, but it is barely visible in the bottom right hand corner of the screen. On the other hand, the Leicestershire site has a very clear link entitled 'library' on the home page which then offers an alternative that is 'A selection of booklets, leaflets and other material produced by Leicestershire Constabulary and its partner agencies, from crime prevention leaflets to guidance and advice'. To illustrate the value of this professionally produced, downloadable material, there is the powerful Domestic Violence publication (Leicestershire Constabulary 2005). This deals in a very direct way with an issue too often neglected by society as a whole, let alone police forces. It provides police and other relevant local contact details, and is not only downloadable in pdf form, but large print, Braille and audio versions are also available.

There are naturally other implications of police electronic communication. For instance, police websites can provide links into various databases that are in the process of changing significant aspects of operational policing. Derbyshire maintains a database of people to whom they can target specific messages and crime alerts (Neighbourhood Watch groups, partner agencies, members of the police force, and particular targets of crime such as owners of Four Wheel Drive vehicles), through the 'Ringmaster' community messaging scheme. Some police forces provide a facility whereby victims of crime can key in a unique record number and check progress in the investigation of the case. Increased interactivity can also be seen in initiatives such as Derbyshire’s online ‘Ask the Chief Constable’ sessions. Web access is widespread in Britain but for such 
initiatives to work there remains a need for easy public access. Derbyshire have experimented with kiosks for this purpose and have positioned one in the new Westfield Shopping Centre in Derby that opened in October 2007. This publicises Safer Neighbourhood activity and provides police contact details. It is just another example of the way that electronic information resources now sit at the heart of police communications activity.

\section{Freedom of information responses}

Both Derbyshire and Leicestershire have Freedom of Information teams serving to manage records for retrieval and to handle responses to freedom of information enquiries. One interviewee commented that police forces, as already information-intensive organisations, depend on good record keeping, but freedom of information, by opening aspects of this to even more intense public scrutiny, has served to sharpen the quality of what they do. High profile failures based on the loss or inadequacies of records are subject to such media and public attention that the record-keeping activity is constantly reviewed and strengthened. It was suggested that, arguably, it is more the human failures of individual officers or units to follow established routines with regard to matters, including record keeping, that are responsible for most failures, not the systems themselves. The number of freedom of information requests received by the two case study forces does not at present seem enormous (390 in Derbyshire during 2006, for example), but both forces noted that requests are increasing both in quantity and in complexity. What is certainly the case is that both Derbyshire and Leicestershire note that freedom of information has resulted in increased workloads. Much of this will be for the preparatory work rather than the actual responses, but the total cost in salaries for a dedicated freedom of information team alone is substantial.

Freedom of information legislation is used by the general public, but the chief type of use as far as police forces are concerned is by the press and other media (an estimate for Leicestershire was that something like $40-45 \%$ of all requests come from the media, with the remaining requests coming from a mix of the general public, victims of crime or accidents, academic researchers and other bodies). It was suggested that the media have become very astute in their use of the Act and in avoiding the exemptions for which the law provides. Some of the requests are effectively 'fishing' for something that might make a story and respondents commented that there is a tendency for the media to use a 'scattergun' approach, sending the same request to all forces in the hope that it will lead to a story. The distinction between 'what is in the public interest', and 'in what the public is interested', is a critical one for the police when deciding how to respond to a freedom of information request. Moreover, the trend towards sensationalism of news means that what is revealed may not mean quite what it at first seems. Take, for instance a Derby Evening Telegraph story headlined 'Dozens of young people given a licence to shoot' (Oakes 2007). This revealed that, of 436 firearms licences issued in the previous year in Derbyshire, 33 were for people who were under seventeen. The headline and even more the subheading 'We force police to reveal number of shotgun permits for under-17s'give the impression that this might be an attempted police cover-up of a dangerous gun problem: the story itself shows that the permits were for gun use under supervision by farmers' children and potential sporting shooters. Freedom of information requests are answered literally from the records available and the answers may not actually address the question in the enquirer's mind. The time limit imposed for a response acts as a constraint on the quality of responses - forces will tend to provide quantitative information (e.g. number of homicides) without reporting the richer, underlying 'sense-making' information (e.g. the percentage of these that were committed by a member of the victim's family). For instance, an enquiry about seizures of explosives might produce a high and rather frightening figure that when broken down consists chiefly of fireworks and gun cartridges not the kind of explosives that might indicate potential terrorist activity. An enquiry as to how many times 
there was a police officer in a particular village might only include formal, logged visits and fail to reveal many other visits either recorded incidentally in other files, or not recorded at all.

However, it was noted that freedom of information is a significant creator of transparency. Desk research carried out in May 2009 revealed that at least 33\% of the 43 forces in England and Wales ${ }^{1}$, including Derbyshire Constabulary, had adopted the practice of publishing online the responses they make to every freedom of information request, via their websites, thus moving the information into a public status. Hampshire Constabulary is a good example of a force that has taken this principle further to include the 'proactive disclosure' of information that might otherwise be potentially subject to freedom of information requests, such as details of the criminal convictions of officers employed by the Constabulary (Hampshire Constabulary 2009). Whilst freedom of information activity continues and increases, it is important to note that any police force deals with countless thousands of enquiries as a matter of routine ('If you want to know the time ask a policeman' as the old music hall song says). It is probable that in the current climate of openness the number of significant enquiries that are now answered as routine (when they might have been avoided in the past) and never reach the status of freedom of information request is considerable. Leicestershire receives about 48,000 media calls per year: the call management system can be overrun by media calls at the times when particular stories emerge (the Constabulary were inundated following any developments to the story relating to the disappearance of Madeleine McCann, for instance, as a result of her parents residing in Leicestershire). To such media calls can be added the freedom of information requests, but even this fails to give any measure of the volume of everyday enquiries to police personnel. Perhaps the only certainty is that public interest in police work will not diminish.

\section{Conclusions}

Police communication is important: democratic societies need open, responsive and accountable police forces. In the UK a combination of factors, including freedom of information legislation, appear to have continued and strengthened a longstanding trend towards an apparent ethos of greater openness and professionalized communication on the part of the police. There is evidence of an acceptance that increased levels of information disclosure are, and should be, the norm, whether for strategic or ethical reasons. Not only is information prepared by professional communicators for publication and broadcasting, but police websites also communicate and act as resource banks for public information about police activities. Online publication has increased the breadth, timeliness and accessibility of information about policing available to the general public, as well as offering new possibilities for two-way interaction between the police and the communities they serve. At the same time the volume and quality of traditional publications has increased. Poor production quality and unenthusiastic distribution might have been common in the past, but today the effort, range and professionalism displayed suggests genuine intent to communicate. It might be argued that this flow of slick, professional communication is just another example of twenty first century media superficiality. However, looked at in a context that includes freedom of information and the general enhancement of police information handling that is in process, this accusation would seem somewhat simplistic.

\footnotetext{
${ }^{1}$ As of May 2009 these included Bedfordshire Police; Cambridgeshire Constabulary; Derbyshire Constabulary; Devon and Cornwall Constabulary; Dorset Police; Durham Constabulary; Dyfed Powys Police; Greater Manchester Police; Hampshire Constabulary; Norfolk Constabulary; North Wales Police; North Yorkshire Police; Northamptonshire Police; Surrey Police; Sussex Police; West Midlands Police.
} 
The public can undoubtedly benefit from what they are able to learn about police activity, and the relations between people and their police forces can also only benefit. For police services, recognition of the centrality of the media as a force in gaining public support and cutting crime has arguably brought about changes in favour of a more open policing culture. Increased opportunities for the public to communicate their views to the police and to the media offer tremendous potential benefit to both police and public: however, there is need for policing organisations to be mindful of ensuring that the voices of all sectors of the community are heard, and not just those of the more vocal and articulate middle classes.

There are however costs. Professional communication costs money and a freedom of information regime costs money. A freedom of information response published on the website of Cambridgeshire Constabulary calculated the total spend on marketing, external communications and press offices for the financial year $2007 / 08$ as $£ 632,250$; this was excluding the costs of responding to freedom of information requests, for which a further 2.25 members of staff were employed (Cambridgeshire Constabulary 2009). The Avon and Somerset Constabulary report that the total staffing costs of complying with the freedom of information legislation as of May 2009 were running at £130,000 a year. Police budgets are not infinitely expandable and if openness and promotional activity were to reach costs levels that threatened operational policing it would not only be police officers who were worried. There is a ratio that balances the ethos of openness with the resource demands that it makes. At present there appears to be a general agreement that the ratio is in an acceptable balance. The future of policing in the UK requires that this continues to be the case, even if the costs continue to rise. The will of governments and the support of voters are needed for openness in policing to be maintained and, when necessary, expanded.

With regard to control of the media agenda, this study suggests that UK police forces have, in some respects, moved further along the continuum towards professional management of the news stories that are published about crime and policing. Police forces are undoubtedly able to benefit from instrumental use of the media as an 'investigative resource' (Innes 1999) and have been increasingly involved in using media professionals to manage their image, whilst reliance on the part of the media for the news and entertainment value of crime and policing stories has arguably resulted in a level of 'collusion' in this image management. There has certainly been an observable shift away from the reactive stance taken by the police in the past towards the media (Ericson et al. 1989). There can be genuine public interest in professional management of the media by the police: for example, to prevent the publication of information that could be prejudicial to a pending court trial. However, this more proactive approach to media management on the part of police services does carry with it a risk to standards of critical investigative journalism (Crandon and Dunne 1997). Nevertheless, it can also be seen that this control has been somewhat counterbalanced by an increased public access to information released under the FOIA that has enabled the media to continue to play a watchdog role, particularly with regard to financial accountability and the exposure of police corruption or malpractice. The rise of online 'citizen journalism' via blogging and the use of mobile devices to capture and broadcast stories, including still and moving images, worldwide in a matter of seconds, has also reduced the levels of control exerted by the police over information disclosure. Indeed, it could be argued that, together with the impact of globalisation, an increased managerialism, technological developments and media diversity, freedom of information measures have led to police services being 'amongst the most watched [organisations] in our society' (Mawby 1999) and their ability to control the news agenda has diminished accordingly.

The balance between the control exercised by the police, and that exercised on the other hand by the media, is clearly not a fixed or static ratio. On the contrary, it is possible to view this balance as a shifting entity that ebbs and flows over time: thus, for example, prior to the initiation of formal police press relations functions 
and a focus on the part of the news media towards investigative journalism, it could be suggested that the balance may have worked in the favour of the media. As police forces have increasingly professionalised the role of press relations, it would be possible to consider that the balance may have moved more in favour of the police and their ability to 'manage' the media. The increased opportunity to interact directly with the public afforded by an emphasis on neighbourhood policing, public consultation and electronic communication, has also offered the police a potential means of bypassing the traditional news media as a communication channel and source of intelligence. However, as noted above, increased expectations of public accountability together with new legislative and technological modalities of regulation, such as the FOIA and new 'democratising' communication media, impose new constraints with regard to police control of information of potential genuine public interest. Despite the resources being devoted by police forces towards professional management of the media, recent evidence from incidents such as the G20 protests suggests that the traditional and new media constitute a vital force as 'watchdog' for modern democracies, and they are still able to act as a significant constraint on the ability of the police to retain control over the disclosure of critical information.

\section{Limitations and further Work}

This paper reports the findings from two small case studies. The limitations of the scope of the empirical work are recognised. The empirical work was carried out as an unfunded study with a view to its acting as a pilot study for subsequent funded work: as such, the study, together with the themes arising from review of the literature, has confirmed the potential of this area as one that deserves further work, particularly with regard to the freedom of information element. Despite the limited scope of the study, the findings support narratives from the literature and suggest that some general conclusions can be drawn with regard to the impact of government drivers towards public communication and the impact of freedom of information legislation, particularly with regard to the shifting nature of police and media relations. It is recognised that co-operation between the police and the media is not a new phenomenon: however, the increased opportunity for public involvement in this relationship does offer potential for genuine and deep-rooted change. It is also recognised that "the media", and indeed "the police", are not a single entity, and therefore the balance may shift differently when considering different police forces and different media. We would suggest therefore that there is much scope to follow up this work with more extensive case study work, and in particular to focus on analysis of the balance between police- and media- initiated press coverage of policing activity in a postFOIA environment.

\section{Acknowledgements}

The authors would like to offer their thanks to members of the Derbyshire Constabulary and Leicestershire Constabulary for their support and co-operation in giving their time and knowledge for the benefit of the research. We would also like to note that some aspects of the work reported here were also published in the proceedings of the GL9 International Conference on Grey Literature, held in Antwerp, December 2007. Permission has been granted from the publishers for further dissemination of the project findings. Our thanks are also extended to the anonymous reviewers of the initial paper, whose detailed and insightful comments enabled the paper to be improved considerably. 


\section{References}

Avon and Somerset Constabulary, 2009. The price of freedom. Available at http://www.avonandsomerset.police.uk/information/foi/foi_information/ThePriceOfFreedom.aspx [Accessed 15 May 2009].

Bichard, M., 2004. The Bichard Inquiry: an independent inquiry arising from the Soham murders. London: Home Office.

Boyle, R., 1999. Spotlighting the Police: Changing UK Police-media relations in the 1990s. International Journal of the Sociology of Law, 27, pp. 229-- 250.

Brodeur, J. and Dupont, B., 2006. Knowledge Workers or "Knowledge" Workers? Policing and Society, 16(1), pp. 7--26.

Cambridgeshire Constabulary, 2009. Freedom of information Request Reference No. 0147/09. Available at http://www.cambs.police.uk/about/freedom of information/disclosure/PUB0147-2009.pdf [Accessed 15 May 2009].

Chermak, S. and Weiss, A., 2005. Maintaining legitimacy using external communication strategies: an analysis of police-media relations. Journal of Criminal Justice, 33, pp. 501-512.

Chibnall, Steve, 1977. Law-and-Order news: an analysis of crime reporting in the British Press. London: Tavistock.

Chibnall, Steve, 1979. The Metropolitan Police and the news media. In Holdaway, S. (ed.) The British Police. London: Edward Arnold, pp. 135-149.

Chinchen, D. and Morris, A., 2005. Getting the balance right: a Metropolitan Police Service perspective on preparing for the Freedom of information Act 2000. Open Government: a Journal on Freedom of information. Available at http://www.opengovjournal.org/issue/view/29 edn. [Accessed 3 September 2008].

Christensen, W. and Crank, J.P., 2001. Police work and culture in a nonurban setting: an ethnographic analysis. Police Quarterly, 4(1), pp. 69--98.

Cohen, S., 2002. Folk devils and moral panics : the creation of the Mods and Rockers. 3 edn. London: Routledge.

Crandon, G.L., 1992. The police and the media: information management and the construction of crime news. Bradford: Horton Publishing.

Crandon, G.L. and Dunne, S., 1997. Symbiosis or vasselage? The media and the law enforcers - the case of Avon and Somerset police. Policing and Society, 8, pp. 77--91.

Derbyshire Constabulary, 2007. Have your say, 2007: Report. Butterley, Derbyshire: Derbyshire Constabulary and Derbyshire Police Authority.

Derbyshire Constabulary, n.d. Young space. Available at http://www.derbyshire.police.uk/youngspace/1.html [Accessed 15 May 2009]. 
Devon and Cornwall Constabulary, 2007. Brixham Police Officers take sticker form in working with the younger residents of Brixham. Press release, 10 October. Available at http://www.devoncornwall.police.uk/v3/news/latest/pressrelease.cfm?id=962 [Accessed 2 September 2008].

Ericson, R.V., Baranek, P.M. and Chan, J.B.L., 1989. Negotiating control: a study of news sources. Milton Keynes: Open University.

Ericson, R.V., Baranek, P.M. and Chan, J.B.L., 1991. Representing order: crime, law and justice in the news media. Buckingham: Open University Press.

Ericson, R.V. and Haggerty, K.D., 1997. Policing the risk society. Oxford: Clarendon Press.

Gottschalk, P. and Solli-Saether, H., 2007. Computer information systems as determinants of police investigation performance: an empirical study. Journal of Computer Information Systems, 47(3), pp. 45--59.

Great Britain, 1998a. Human Rights Act 1998. London: Office of Public Sector Information.

Great Britain, 1998b. Public Interest Disclosure Act 1998. London: Office of Public Sector Information.

Great Britain, 2000. Freedom of information Act 2000. London: Office of Public Sector Information.

Hall, S., Chritcher, c., Jefferson, T., Clarke, J. and Roberts, B., 1986. Policing the crisis: mugging, the State, and law and order. 2 edn. Oxford: Macmillan Education.

Hampshire Constabulary, 2009. Proactive disclosure of information. Available at http://www.hampshire.police.uk/Internet/rightinfo/freedom of information/informationclasses/proactive/index.htm [Accessed 15 May 2009].

Home Office, 2004. Building communities, beating crime: a better Police Service for the 21st Century. Command Paper 6360. Available at http://www.homeoffice.gov.uk/documents/wp04_complete.pdf [Accessed 2 September 2008].

Home Office, 2006. Background to local policing summaries. Available at http://police.homeoffice.gov.uk/publications/police-reform/Police_summaries_Background.pdf [Accessed 1 September 2008].

Home Office, 2008. From the neighbourhood to the national: policing our communities together. Command Paper 7448. Available at http://police.homeoffice.gov.uk/publications/police-reform/Policing_GP/ [Accessed 2 September 2008].

Innes, M., 1999. The media as an investigative resource in murder enquiries. British Journal of Criminology, 39(2), pp.269-286.

Leicestershire Constabulary, 2005. Domestic violence. Available at http://www.leics.police.uk/files/library/documents/domesticviolence.pdf [Accessed 2 September 2008].

Leishman, F. and Mason, P., 2003. Policing and the media: facts, fictions and factions. Cullompton: Willan.

Luen, T.W. and Al-Hawamdeh, S., 2001. Knowledge management in the public sector: principles and practices in police work. Journal of Information Science, 27(5), pp. 311--318. 
Mawby, R.C., 1999. Visibility, transparency and police-media relations. Policing and Society, 9(3), pp. 263286.

Mawby, R.C., 2002a. Policing images: policing communication and legitimacy. Cullompton: Willan.

Mawby, R.C., 2002b. Continuity and change, convergence and divergence: the policy and practice of police media relations. Criminology and Criminal Justice, 2(3), pp.303-324.

Muller, E.R., 2002. Policing and accountability in the Netherlands: a happy marriage or a stressful relationship? Policing and Society, 12(4), pp. 249-- 258.

National Centre for Policing Excellence, 2005. Code of Practice on the Management of Police Information. Wyboston: Centrex.

National Centre for Policing Excellence, 2006. Guidance on the Management of Police Information. Wyboston: Centrex.

Oakes, C., 2007. Dozens of young people given a licence to shoot. Derby Evening Telegraph, 27 September.

Parliament, 1999. Modernising Government. Command Paper 4310. London: Stationery Office. Available at http://www.archive.official-documents.co.uk/document/cm43/4310/4310.htm [Accessed 3 September 2008].

Rayner, G., 2005. Shot Brazilian was here with a fake visa. Daily Mail,25 July. Available at http://www.dailymail.co.uk/news/article-357458/Shot-Brazilian-fake-visa.html [Accessed 2 September 2008]

Readhead, I., 2004. Countdown to freedom day. Policing Today, 10(4), pp. 17--19.

Readhead, I., 2007. Question time. Police Review, (24 August 2007), pp. 24-25.

Reiner, R., 2000. The politics of the police. $3^{\text {rd }}$ ed. Oxford: Oxford University Press.

Reiner, R., 2008. Policing and the media. In Newburn, T. (ed.) Handbook of Policing, $2^{\text {nd }}$ ed. Cullompton: Willan, pp.313-335.

Schlesinger, P. and Tumber, H., 1994. Reporting Crime: the Media Politics of Criminal Justice. Oxford: Clarendon Press.

Screene, L., 2005. How prepared are public bodies for the implementation of the UK Freedom of information Act in January 2005? Records Management Journal, 15(1), pp. 34--42.

Shepherd, E. and Ennion, E., 2007. How has the implementation of the UK Freedom of information Act 2000 affected archives and records management services? Records Management Journal, 17(1), pp. 32--51.

Stenson, K., 1993. Community policing as a governmental technology. Economy and Society, 22(3), pp. 373$-387$.

Travis, A., 2008. Crime rates expected to soar as economic difficulties deepen. The Guardian, 18 July, pp. 6. 
Van Den Broek, T., 2002. Keeping up appearances? A community's perspective on community policing and the local governance of crime. Policing: an International Journal of Police Strategies and Management, 25(1), pp. 169--189.

Walters, S., 2006. Stockwell victim was 'high on cocaine'. Mail on Sunday,11 June. Available at http://www.mailonsunday.co.uk/news/article-390104/Stockwell-victim-high-cocaine.html [Accessed 2 September 2008]. 